\title{
Contexto histórico e artístico de produção do fenômeno Racionais $\mathrm{MC}^{\prime}$ s:
}

uma ruptura musical ${ }^{*}$

TIARAJU D'ANDREA**

\begin{abstract}
RESUMO: Diferentemente do que já foi realizado de maneira corrente, este artigo não analisará nenhuma letra de rap dos Racionais $M C^{\prime}$ 's. A obra do grupo será debatida por meio de três feixes interpretativos. Cada um desses feixes contemplará cada uma das três sessões do texto. Na primeira e na segunda sessão, serão realizadas análises externas à obra do grupo. Na primeira se descreverá o contexto histórico no qual emergiram os Racionais $M C^{\prime}$ 's, dando ênfase ao emblemático ano de 1993. Na segunda sessão se tratará do contexto artístico do começo da década de 1990. Um dos pressupostos deste texto é o de que não é possível compreender uma obra artística sem compreender o contexto no qual ela foi produzida e como esse contexto se relaciona com a obra e com sua potencial visibilidade. A terceira sessão propõe uma análise musicológica do rap produzido pelos Racionais $M C^{\prime}$ 's atribuindo a algumas características musicais propostas pelo grupo o sucesso que o mesmo obteve.
\end{abstract}

PALAVRAS-CHAVES: Racionais MC's; rap; anos 1990; sujeitos periféricos; neoliberalismo.

\section{Historical and artistic context of production of the phenomenon Racionais MC's: a musical break}

\begin{abstract}
In this article, unlike what has been done, will not be analyzed the lyrics of Racionais MC's. The work of the group will be debated through three interpretive ways. Each of them will be contemplated into three sessions. In the first and second sessions, external analyzes will be carried out on the group's work. The first part describes the historical context in which Racionais MCs emerged, emphasizing the emblematic year of 1993. In the second one, the artistic context of the early 1990s will be discussed. One of the approach of the article says that it is not possible to understand an artistic work without understanding the context in which it was produced and how this context is related to the work and its potential visibility. The third session proposes a musicological analysis of the rap produced by Racionais MC's, attributing it to some musical characteristics proposed by the group the success that it obtained.
\end{abstract}

KEYWORDS: Racionais MC's; rap; 1990's; peripheral subject; neoliberalism.

\footnotetext{
* Este artigo está baseado na tese de doutorado do autor, intitulada A Formação dos Sujeitos Periféricos: Cultura e Política na Periferia de São Paulo, defendida no Departamento de Sociologia da Universidade de São Paulo, no ano de 2013, sob a orientação da Professora Doutora Vera da Silva Telles.

${ }^{* *}$ Tiaraju D'Andrea é Doutor em Sociologia pela Universidade de São Paulo (USP) e pesquisador convidado da École des Hautes Études en Sciences Sociales (EHESS), Paris, França. A agência financiadora da pesquisa é a FAPESP (Fundação de Amparo à Pesquisa do Estado de São Paulo). E-mail: tiarajupablo@gmail.com
} 
s quase quatro séculos de escravidão deixaram um imenso legado na sociedade brasileira. Com a perenidade de formas e relações fundadas nesse tipo de regime, o Brasil contemporâneo segue apresentando racismo estrutural, desigualdade econômica e um elevado nível de repressão social. Juntamente a esse legado escravocrata, outro fenômeno histórico cujas estruturas não foram desmontadas foi a ditadura militar ocorrida oficialmente entre os anos 1964 e 1985.

Com o fim da ditadura no segundo quinquênio da década de 1980, abriu-se no Brasil um cenário propício para a arte crítica. É nesse momento que explodem o samba de raiz e o rock nacional. E é nessa encruzilhada histórica que o rap surge no cenário brasileiro, para então se consolidar nos anos 1990.

Tendo como cenário a década de 1990, nosso argumento é o de que o rap nacional vocalizou e expressou a crítica de um setor social que ainda padecia (e padece) do legado escravocrata. No entanto, é apenas no fim da ditadura, que no Brasil ocorre quase que simultâneo com a chegada do rap, que esta crítica feroz foi possível de ser publicizada. Ou seja, de maneira paradoxal, o rap é expressão das feridas não fechadas da ditadura ${ }^{1}$, mas também só foi possível de ser publicizado pelo fim dela. Ainda encurralado por estruturas seculares de opressão, o rap surge enquanto verborragia e enquanto necessidade de fala e tomada da palavra.

Para este artigo, outro acontecimento histórico iria, paradoxalmente, abrir caminhos para a publicização do rap no Brasil: a queda do Muro de Berlim e a crise da esquerda em nível mundial. Por um lado, a desestabilização do bloco socialista diminuiu o potencial político da esquerda tradicional e de seus pressupostos. Por outro lado, a ascensão do neoliberalismo nesse período acarretou o aumento da pobreza e da violência nos bairros populares, tendo desse modo lançado as bases para a afirmação do rap enquanto crítica social. Desse modo, o rap no Brasil se afirma a partir de uma dupla ruptura: com a esquerda tradicional, ao afirmar que a transformação social

\footnotetext{
${ }^{1}$ Cabe notar que diversos avanços ocorreram na sociedade brasileira no que tange à democratização política do país após 1985. No entanto, o legado do período ditatorial deixou marcas muito profundas na sociedade e ainda pouco estudadas, dado que o termo "democracia", aplicado ao período pós-1985, desestimulou a necessidade do entendimento de como estruturas consolidadas na ditadura perduraram na sociedade. Sobre o assunto, o filósofo Paulo Arantes afirmou: "o que resta da ditadura? Tudo, menos a ditadura" (ARANTES, 2010).
} 
viria da periferia, e não do mundo do trabalho, e com o pensamento neoliberal, ao denunciar a miséria social que esta corrente política produzia.

\section{Contexto histórico de produção do fenômeno Racionais MC's}

\section{3: um ano emblemático²}

O ano de 1989 foi particularmente importante no Brasil, dado que representou o começo do fim de uma era de efervescência para as classes populares baseada em organizações coletivas clássicas como os movimentos sociais, os partidos políticos de esquerda e os sindicatos. No que tange especificamente aos bairros populares, podem-se elencar três fatores que foram decisivos para o refluxo dos movimentos sociais, populares e das organizações comunitárias que neles atuavam: a queda do Muro de Berlim e a crise do ideário socialista em escala mundial; a derrota de Lula para Collor de Melo na eleição presidencial de 1989, que teve por decorrência uma série de medidas internas ao Partido dos Trabalhadores, dentre as quais o fim do trabalho de base e; o paulatino cerceamento ao trabalho da Teologia da Libertação nas periferias paulistanas.

Segundo o historiador Lincoln Secco, em seu livro História do PT (SECCO, 2011), o desaparecimento dos núcleos de base foi ocorrendo de forma paulatina e selou a profissionalização da militância internamente ao partido. Por sua vez, a derrota de Luiz Inácio Lula da Silva para Fernando Collor de Mello nas eleições de 1989 fez com que o PT iniciasse um processo visando o pragmatismo eleitoral, que teve por consequência o aumento da abrangência de seu arco de alianças, inclusive com partidos de centro e de direita, e a perda de profundidade, caracterizada pela sua relação com a base.

Outro fator de perda de referencial político nas periferias se deu com a diminuição da presença de agentes ligados ao catolicismo de esquerda. A capilaridade que a Teologia da Libertação havia conquistado nos bairros populares foi decisiva nas

\footnotetext{
2 Para uma análise sobre o rap "Fim de Semana no Parque", lançado pelos Racionais MC's no ano de 1993, ver o artigo: “Fim de Semana no Parque: vinte anos", de Tiaraju D’ Andrea (2013).
} 
mobilizações contra a carestia, nos finais dos anos 1970, assim como na fundação do PT e do MST.

Tal presença do catolicismo de esquerda na política nacional nunca ocorreu sem tensão no que tange ao âmbito interno à igreja católica. Assim sendo, um ponto de inflexão decisivo nessas disputas ocorreu em 1989, quando sob ordens do Papa João Paulo II, houve uma ingerência da igreja católica nas comunidades de base, visando seu enfraquecimento.

O desaparecimento da movimentação política engendrada pelo PT nas periferias de São Paulo e o fim das discussões fomentadas pelas CEBS foram fatores fundamentais para a falta de representatividade política que passou a assolar os bairros populares à época.

Se por um lado o PT e as CEBs desapareciam da periferia, Paulo Maluf assumia como prefeito de São Paulo em um mandato entre 1993 e 1996. Nesse período, sua gestão foi marcada por remoções de favelas; privatização de serviços públicos; vertiginoso decréscimo na qualidade em áreas como educação e transportes públicos; políticas populistas como o Projeto Cingapura; evidentes desigualdades na alocação de recursos municipais entre bairros periféricos e bairros de elite, do qual se sobressaem os gastos em pontes, avenidas e viadutos na região sudoeste e; por fim, escândalos de corrupção.

No âmbito nacional, o país adentrava 1993 com a posse do presidente Itamar Franco, substituindo Fernando Collor de Mello, que renunciou após um processo de Impeachment.

Com um prefeito de direita que fazia retroceder avanços conquistados a duras penas, somadas à deposição de um presidente por causa de escândalos de corrupção, ficava mais difícil para a população em geral se reconhecer na política institucional. Como se não bastasse, já não mais existiam os núcleos do PT e das CEBs nas periferias. Assim começava 1993.

No âmbito econômico, o país cada vez mais se ressentia das medidas neoliberais colocadas em prática já nos primeiros anos da década de 1990. Os serviços pú- 
blicos se deterioraram e os empregos formais caíram sobremaneira. Com isso aumentou a informalidade e, sobretudo, o desemprego passou à ordem do dia das classes populares.

Se por um lado grande parte da mão de obra se viu excluída do trabalho formal, para os que ficaram a realidade não era tão animadora. Os salários passaram a cair em todos os setores. Segundo o economista Márcio Pochmann, entre 1995 e 2004, a renda do trabalho perdeu $9 \%$ do seu peso relativo na renda nacional, ao passo que a renda da propriedade cresceu 12,3\% no mesmo período (POCHMANN, 2012, p. 9). Junto com os salários, cai o número de trabalhadores sindicalizados e diminui o número de greves.

Se é fato que as medidas neoliberais pioravam as condições de vida de trabalhadores e moradores de bairros populares, é bem verdade também que alguns setores sociais enriqueceram, sobretudo agentes ligados ao setor financeiro. Muitos produtos importados chegaram ao país, já livres de restrições. A burguesia paulistana saudava tais modificações e comemorava a chegada de um novo estilo de vida. É nessa época que proliferam os condomínios fechados e o consumo de luxo. Também era propagandeado como sinal de progresso o aumento do número de automóveis nas ruas, assim como o fato de São Paulo ter se transformado na cidade com a segunda maior frota de helicópteros do mundo.

Todas essas mudanças de cunho econômico, político e social vieram acompanhadas de um intenso aparato propagandístico dos valores neoliberais. Dessa forma, um discurso de prosperidade se impunha sobre toda sociedade. Tal discurso reverberava em muitos estratos sociais pregando o faça você mesmo e o empreendedorismo no plano econômico. Impulsionados pela possibilidade de aquisição de produtos importados, o consumismo e a ostentação se colocaram como balizadores das relações sociais. Condutas individualistas eram estimuladas e tudo aquilo que denotasse ser comum ou público era criticado em nome das vantagens do privado. A partir desse discurso, passam a ser justificados os condomínios fechados, a privatização da gestão urbana e a substituição dos serviços públicos pelos serviços privados, por meio do desmonte do Estado, dentre outras medidas. 
Como síntese deste período, pode-se afirmar que à falta de representatividade política e ao descrédito nas instituições somaram-se os baixos salários e o desemprego em massa, que por sua vez se mesclaram ao individualismo utilitarista cada vez mais em voga e à privatização da vida e dos espaços públicos. Por sua vez, estas novidades, ao se incrustarem em bases assentadas em nossa sociedade e cuja origem são a escravidão e o autoritarismo, fizeram da década de 1990 um caldeirão explosivo no plano social.

Os primeiros anos da década de 1990 foram marcados por uma violência generalizada do Estado contra setores populares e marginalizados da sociedade. Em 02 de outubro de 1992, uma intervenção da Polícia Militar de São Paulo, liderada pelo Coronel Ubiratan Guimarães, na Casa de Detenção de São Paulo resultou na morte de 111 detentos $^{3}$. Na madrugada de 23 de julho de 1993, oito crianças e adolescentes (dos quais apenas dois com mais de dezoito anos) foram assassinadas em frente à Igreja da Candelária, no centro do Rio de Janeiro. Os assassinos eram policias e ex-policiais. Um mês após o assassinato de crianças e adolescentes no centro do Rio de Janeiro, outro massacre impacta o país: desta vez no bairro de Vigário Geral, na zona norte dessa cidade, ocorrida no dia 29 de agosto de 1993.

Para além dos três massacres ocorridos em tão pouco tempo, outros eventos expressavam o grau de tensão acumulada na sociedade brasileira no período em questão. Em 18 de outubro de 1992, um domingo de sol, uma série de brigas e roubos ocorridos nas praias cariocas são veiculados nos jornais de grande circulação e pela mídia televisiva. Tal episódio, intitulado como Arrastão, punha a nu a fragilidade da segurança pública nos bairros de elite do Rio de Janeiro. Também nessa época começou a se tornar pública a violência que ocorria nos bailes funks dos subúrbios cariocas, motivado pela rivalidade entre gangues. Por sua vez, outro tema recorrente era a disputa entre facções pelos pontos de venda de drogas no Rio de Janeiro e os confrontos entre estas e a polícia.

\footnotetext{
${ }^{3} \mathrm{O}$ número oficial de mortos é contestado por familiares de detentos e organismos de Direitos Humanos, que afirmam ser maior o número de vítimas do massacre.
} 
Em outro âmbito, o futebol também expressava as tensões patentes do momento4. Nunca como entre os anos 1990 e 1995, a violência entre torcidas de futebol resultou em tantas mortes, tanto no Rio de Janeiro como em São Paulo. Foi nessa época que as chamadas "torcidas organizadas" passaram à pauta pública, acusadas de serem muito mais uma congregação de vândalos e arruaceiros do que um núcleo de sociabilidade 5 .

Até este ponto, o texto esboçou uma breve descrição do contexto econômico, político e social do ano de 1993, com o evidente legado de acontecimentos também ocorridos no ano de 1992. Nesses anos, o país no geral, e São Paulo especificamente, enredavam-se em um contexto no qual se mesclavam privatizações, desemprego recorde, malufismo, remoções, favelização, crescimento demográfico das periferias, perda de referências em partidos políticos e movimentos sociais, crescimento das torcidas organizadas e do movimento hip-hop enquanto referências identitárias da juventude da periferia. Em paralelo (e em decorrência) a essas rápidas mudanças ocorridas nos planos político, econômico e social, a violência permeava as relações sociais e se expressava por massacres e taxas de homicídios recordes até então. Um clima de tensão pairava por todos os segmentos sociais aumentando o potencial conflitivo daquela conjuntura.

A partir do ano de 1993, as taxas de homicídios na cidade de São Paulo passam a subir atingindo níveis alarmantes. O pico nessa taxa ocorre entre os anos 1997 e 1999, passando a decair levemente até 2004 e de maneira acentuada até 2011 .

Em meados da década de 1990, bairros da zona sul de São Paulo possuíam índices de assassinatos equiparáveis às regiões mais violentas da Colômbia ou de países em guerra civil. Nessa época, o bairro do Jardim Ângela é considerado o mais violento do mundo e, juntamente aos bairros do Jardim São Luís e do Capão Redondo,

\footnotetext{
${ }^{4}$ Neste âmbito, cabe lembrar o acidente ocorrido no estádio do Maracanã em junho de 1992 na final do Campeonato Brasileiro disputada entre Flamengo e Botafogo, resultando em sete vítimas fatais.

${ }^{5}$ Nessa época, cresce o fenômeno das torcidas organizadas e adesão de jovens a estas organizações. Para esta pesquisa, o crescimento das organizadas e do movimento hip-hop, na época e sobretudo em São Paulo, está totalmente vinculado à diminuição da presença de agentes sociais como partidos políticos, sindicatos e movimentos sociais nas periferias urbanas.

${ }^{6}$ Fonte: PRO-AIM, SIM - Sistema de Informação sobre Mortalidade, Município de São Paulo. Para um aprofundamento da discussão sobre a variação das taxas de homicídio na cidade de São Paulo, ver Telles (2012).
} 
conformam o que se denominou "triângulo da morte". Configurava-se um cenário de total esgarçamento do tecido social, com baixos índices de confiabilidade nas redes sociais de vizinhança. $\mathrm{O}$ individualismo imperava entre os pobres, o medo era sistemático, a tensão era um imperativo e sobreviver, fundamentalmente entre jovens, uma arte? $^{7}$

Em grandes traços, este foi o contexto social, político e econômico dos bairros periféricos de São Paulo na década de 1990. Uma mescla de desesperança, raiva, fracasso, resignação, pobreza, sangue, insegurança. Enfim, desespero. A civilização havia chegado ao limite e se equilibrava na beira de um abismo, impondo as perguntas mais básicas da espécie: a comida ou a fome, a vida ou a morte. Não havia outra saída a não ser tentar buscar a esperança no mais básico dos instintos, aquele cujo objetivo é perpetuar a espécie. Uma das saídas encontradas foi por meio da produção artística, que passou a ser engendrada nas periferias. Um discurso que balizou essa produção foi o do rap, fundamentalmente pelo grupo Racionais $M C^{\prime}$ s, que soube ser expressão e ao mesmo tempo expressar os dilemas e os sonhos dessa população naquele tempo histórico.

\section{Contexto artístico de surgimento do fenômeno Racionais}

\section{MC's}

O primeiro ponto de abordagem para o entendimento do contexto artístico de formação do fenômeno Racionais MC's no primeiro quinquênio da década de 1990 é o que se refere ao fim da ditadura militar no Brasil. Nesse período, a música brasileira teve seu potencial crítico e criativo coagido pela conjuntura política do país. Dessa forma, muitos artistas se exilaram e/ou tiveram que utilizar de uma série de subterfúgios poéticos e literários para formularem a crítica de maneira a não serem censurados. No entanto, a restrição à expressão artística no Brasil não impediu que uma crítica de esquerda fosse veiculada. Pelo contrário, segundo artigo famoso do crítico literário Roberto Schwarz (1978), o golpe militar desencadeou um processo inesperado: mesmo

\footnotetext{
7 Para uma análise aprofundada e ampla das condições socioeconômicas do bairro do Capão Redondo na década de 1990, ver Carril (2006).
} 
obtendo o poder político, a direita conservadora perdeu a relativa hegemonia cultural para a esquerda. Segundo o cientista político André Singer (2012; 2012a), essa hegemonia cultural da esquerda teve seu ápice entre os anos 1978 e 1988, acompanhando um período de grandes mobilizações políticas no país. Essa hegemonia começa a arrefecer com o passar dos anos da década de 1990, com o primado do pensamento neoliberal. Enquanto expressão artística da periferia, os Racionais foram um fenômeno possível de existir pelo fim da ditadura e um quadro de maior distensão política do país, pois não havia espaço para esse tipo de questionamento na época ditatorial. De certo modo, o fim da hegemonia cultural da esquerda também propiciou a visibilidade do rap crítico, que passou a ocupar um terreno que aos poucos foi ficando vazio, o da música popular crítica e de esquerda.

Tomando como base a senda argumentativa aberta por Roberto Schwarz e André Singer, e tentando entender a relação entre aspectos históricos e o contexto de surgimento dos Racionais MC's, este texto discorrerá brevemente sobre alguns aspectos que compreendem o período que vai de 1985 a 1989.

Após o fim oficial da ditadura militar, no ano de 1985, o país vivia um momento de euforia. Nesse período, houve uma efervescência crítica no país, acompanhando a força dos movimentos sociais que influenciavam a cena pública até o começo de seu descenso, em 1989.

Como exemplo, destacam-se uma série de novelas (veículo de grande alcance social) que satirizaram e criticaram o sistema político e as desigualdades sociais. Esses foram os casos de Vale Tudo e Que Rei Sou Eu? Chico Buarque apresentava em 1984 seu Vai Passar, simbolizando em forma de samba-enredo o passamento da ditadura militar. É também nesse período de abertura política que muitas escolas de samba desfilaram um sem fim de temas de crítica social.

Voltando ao último quinquênio da década de 1980, vale expor que, possivelmente, em nenhum outro período, seja ele anterior ou posterior a esse, as escolas de samba foram tão críticas. É a partir também de 1985 (por uma coincidência histórica que talvez não seja tão coincidência assim, e que mereceria ser mais bem estudada) que ocorre a volta por cima do samba fundo de quintal, um samba de raiz cujo terreno de cultivo foram os quintais das casas suburbanas. Faz-se interessante notar que esse 
samba veio a disputar a hegemonia da black music entre a população negra das classes populares.

É também na segunda metade dos anos 1980 que o rock brasileiro se afirma enquanto gênero musical crítico e multitudinário, provando que tinha espaço em um país musicalmente autossuficiente. É nesse contexto artístico que o rap nacional engatinhava, dando literalmente seus primeiros passos musicais nos encontros de jovens nas estações centrais do metrô em São Paulo.

Cabe ressaltar que, no caso do movimento hip-hop, houve a absorção de um importante legado deixado pela black music. Porém, é interessante notar que muitos sambistas criticaram o movimento da black music hegemônico nas periferias urbanas na passagem dos 1970 para os anos 1980. As alegações eram várias, e uma delas residia numa certa descaracterização da música negra por parte dessa vertente. O sambista Nei Lopes foi crítico profundo da black music, e em contraposição a ela, João Nogueira fundou o Clube do Samba. No entanto, Geraldo Filme, sambista negro de São Paulo, tinha opinião diferente e chegou a fazer um samba em homenagem a essa vertente da música negra. Diz uma passagem da letra: "vamos balançar/quem é que não vem/ é nova bossa o balanço gostoso que não falte ninguém" 8 .

Polêmicas à parte, o fato é que a black music exerceu grande influência num amplo setor social, sobretudo a juventude negra e pobre moradora dos bairros populares que entre as décadas de 1970 e 1980 dançou esse ritmo em bailes e discotecas (CUÍCA; DOMINGUES, 2009; DJ TR, 2007). No Brasil, esse gênero foi absorvido e divulgado com temáticas ligadas à realidade brasileira pela obra de artistas como Hyldon, Cassiano, Bebeto e, fundamentalmente, Tim Maia e Jorge Benjor. Ídolos da juventude negra moradora de bairros populares, Tim Maia ${ }^{9}$ e Jorge Benjor deixaram um legado musical incomensurável, influenciando toda uma geração de artistas posteriores. No caso de Jorge Benjor, a síntese do samba e do rock realizada nas composições

\footnotetext{
8 Canção Vamos Balançar, de Geraldo Filme.

${ }_{9}^{9}$ Pequena nota sobre gosto de classe e estilo de vida: há alguns anos a Editora Abril lançou coleções com as obras completas de Chico Buarque e Tim Maia. A cada semana, um CD chegava até as bancas de jornal, ficando disponível ao público. Num bairro de periferia da zona leste de São Paulo, perguntei ao jornaleiro sobre as preferências do público. A resposta foi taxativa: "Tim Maia vende cinco vezes mais".
} 
desse artista abriu caminhos insuspeitáveis para a música popular do país. O rap brasileiro é devoto desta vertente da música popular que, como o próprio rap, recriou em solo brasileiro um gênero negro e estadunidense.

No caso específico dos Racionais MC's, Jorge Benjor é a grande referência. O cantor é citado textualmente em algumas letras do grupo. Também foi convidado pelo grupo para abrir um show que depois virou um $\mathrm{DVD}^{10}$. Em entrevista concedida por Mano Brown ao programa televisivo Roda Viva, Jorge Benjor foi citado como sua principal influência ${ }^{11}$. O cantor também teve um refrão sampleado em um dos principais sucessos dos Racionais, o rap "Fim de Semana no Parque".

Jorge Benjor possui uma importância ímpar na música brasileira, maior inclusive do que o reconhecimento que obteve. Sua obra representa um importante ponto de encontro entre o samba e o rock. Entre o nacional e o internacional. Cabe lembrar também que Jorge Benjor foi um dos primeiros artistas a cantar temas negros em suas canções.

Sobre o assunto, cabe destacar que outro elemento de vital importância na obra dos Racionais foi a visibilidade da luta e da afirmação do negro no Brasil. Luta esta que foi potencializada por três fenômenos históricos quase que simultâneos: o fim da ditadura militar, e a consequente possibilidade de visibilidade e extensão das lutas afirmativas; a constituição brasileira promulgada em 1988 e que mobilizou uma série de setores sociais preocupados em verem atendidas suas demandas, da qual o movimento negro foi um de seus protagonistas, e; o fato de no ano de 1988 ter sido o do centenário da abolição da escravatura no Brasil, data que potencializou publicamente ainda mais as demandas reivindicativas desse setor social. Somada à força pública desse movimento social, os Racionais, via rap estadunidense, foram influenciados por ícones da cultura negra daquele país como Malcom X e Martin Luther King. A partir da absorção desse legado, a denúncia radical contra o racismo fez dos Racionais um dos maiores porta-vozes da questão naquele momento histórico, influenciando o posicionamento de toda uma geração de negros moradores de bairros populares, que

\footnotetext{
${ }^{10}$ Lançado em 2006, o nome do DVD é Mil Trutas, Mil Tretas. O mesmo contém imagens de espetáculos dos Racionais MC's e dois documentários: um onde se apresenta a história musical do Capão Redondo, dirigido por Mano Brown, e outro sobre os bailes blacks de São Paulo.

${ }^{11}$ Essa entrevista foi concedida ao programa Roda Viva, da TV Cultura, em agosto de 2007.
} 
passou a ter uma consciência mais abrangente de sua negritude e da sua condição social ${ }^{12}$.

Especificamente entre os anos de 1992 e 1994, contexto histórico da explosão dos Racionais MC's nas periferias de São Paulo, o gênero musical hegemônico era o samba romântico, (mal) denominado pagode. A maior parte desses grupos eram oriundos da periferia de São Paulo e sua maior expressão era o Grupo Raça Negra, que pouco discutia a questão negra no Brasil e, fazendo música romântica, quebrou vários recordes em venda de discos. A vertente aberta por esse grupo abriu caminho para outros grupos correlatos como Negritude Júnior, Só Pra Contrariar, Katinguelê, Sem Compromisso, Malícia, entre muitos outros. Cabe lembrar que, oriundos da mesma situação e condição social dos cantores de rap, a relação entre ambos os gêneros foi perpassada por alianças e alguma tensão. No entanto, esta relação colocada no plano micro só expressava as relações históricas de tensões e alianças entre duas vertentes da música negra: o samba e a black music.

Além do pagode, outro fenômeno de vendas naqueles anos era Jorge Benjor, cuja volta por cima após longos anos de ostracismo se daria com canções de letras "pegajosas" e ritmos dançantes. As mais expressivas desse momento são Alô Alô W Brasil e Engenho de Dentro, tocadas até o cansaço pelas rádios. Outro sucesso da época era o rapper branco da zona sul carioca Gabriel O Pensador, que com vantagens comparativas no acesso a rádios e gravadoras, com relação aos seus congêneres pobres da periferia de São Paulo, estourava com o sucesso Lôra Burra.

Como se não bastasse, a efervescência cultural do período seria marcada pelo assentamento da música dançante da Bahia, que pela primeira vez na história ultrapassava em importância e veiculação os sambas de enredo do Rio de Janeiro. Essa explosão da música baiana nesse período abriu caminho para o surgimento de cantores e grupos desse estado que, produzindo músicas de apelo dançante, romântico e/ ou

\footnotetext{
${ }^{12}$ Segundo um jovem morador da periferia leste de São Paulo, em entrevista concedida ao pesquisador: "só prestei atenção na questão da discriminação racial depois que escutei os Racionais". Por sua vez, sobre o assunto, uma importante estudiosa da questão juvenil em São Paulo afirmou certa vez: "o rap deu um novo alento ao movimento negro".
} 
sexual, ocuparam um espaço ímpar no mercado fonográfico e no cenário musical brasileiro. É o caso de nomes como Chiclete com Banana, É O Tchan, Daniela Mercury, Carlinhos Brown e Ivete Sangalo, dentre tantos outros.

Isto posto, cabe ressaltar, como é possível observar nesta breve análise sincrônica, a ausência de expressões críticas nos grupos e cantores famosos naquele primeiro quinquênio dos anos 1990. Entre o romantismo do pagode, de São Paulo; o facilismo dançante provindo do Rio de Janeiro e; o ritmo lúdico da Bahia, emerge o rap crítico, na mesma zona simbólica de atuação desses outros fenômenos musicais (periféricos e negros).

Cabe aqui o seguinte comentário: ao mesmo tempo em que começam a surgir tendências adocicadas e domesticadas, coadunadas com o pensamento único do momento, o rap por canais insuspeitos, por vezes inesperados, que passavam pelas posses $^{13}$, pelos pontos de encontros e ressignificando e reatualizando a atuação e o discurso das CEBs e do PT nas periferias, uma das fontes da qual o rap bebeu, demonstrava como a pulsão crítica não havia desaparecido. Se por um lado a crítica de esquerda perdia força, e isso se verificava na produção cultural, outros agentes passaram a ocupar o espaço da crítica social.

\section{O rap dos Racionais enquanto ruptura musical}

Após apresentar brevemente o contexto histórico e artístico externo ao grupo e que embasaram a potência do rap dos Racionais $\mathrm{MC}^{\prime}$ s, este artigo tratará brevemente sobre a forma como o grupo apresentou seu conteúdo.

$\mathrm{Na}$ tentativa de tratar o terror como terror, e apresentar com uma radicalidade inédita as mazelas da sociedade brasileira, os Racionais MC's representaram musicalmente uma segunda dupla ruptura, desta vez no âmbito musical14. De um lado,

\footnotetext{
${ }_{13}$ Posses eram locais onde se divulgava a cultura hip-hop. Havia centenas delas nas periferias de São Paulo na década de 1990. Nessas posses haviam apresentações musicais, reuniões políticas, encontros, dentre outras atividades. Elas serviram como articuladoras e divulgadoras do rap e do movimento hiphop.

${ }^{14}$ A primeira dupla ruptura, como já apresentado, foi de ordem política: de um lado, os Racionais MC's romperam com o paradigma clássico da esquerda de que a transformação social viria da classe trabalhadora. No rap dos Racionais, há um protagonismo do povo periférico. Por outro lado, os Racionais
} 
uma ruptura poética, expressa no ineditismo do conteúdo de suas letras. De outro, uma forma musical adequada à enunciação desse conteúdo e que também vem a romper com uma dada tradição musical brasileira. Retomando a afirmação do crítico musical Walter Garcia (2006), o sucesso dos Racionais teria ocorrido pela perfeita adequação entre forma e conteúdo. Este artigo arrisca dizer que a afirmação do crítico pode se estender ao rap no geral.

Ainda baseando-nos em uma proposição de Walter Garcia (2006), para quem a temática fulcral da obra dos Racionais é a violência, sugere-se neste texto que tal violência, apresentada publicamente de maneira nunca antes vista, dialogava criticamente com discursos de prosperidade propalados em meados da década de 1990, e dialogava também com tradições hegemônicas da música popular brasileira cujo cerne teriam sido a síntese acrítica dos contrários que compõem nossa sociedade e a celebração de uma dada modernização expressa de maneira dócil por um estamento social que foi capaz de fazer reverberar seu ponto de vista e torná-lo hegemônico: a classe média carioca.

Assim sendo, e novamente retomando Walter Garcia (2006), se os Racionais tiveram como ponto central de sua obra a violência da sociedade brasileira, e se a eficácia de transmissão de sua mensagem ocorreu por uma perfeita adequação entre conteúdo e forma, é porque os Racionais, segundo este texto, souberam falar da violência de um modo violento.

Partindo desta hipótese, realizaremos uma breve problematização musicológica da forma rap nos Racionais $\mathrm{MC}^{\prime}$ s, tentando compreender como a construção desta forma imbrica-se com sua temática principal: a violência.

Seguem na sequência algumas hipóteses de como a forma musical do rap e a violência como tema se fundem:

1) O rap é império das consoantes contra as vogais. Canto sem melodia (ou com pouca melodia), utilizando ao extremo as consoantes, gerando violência anatômica. Na geração ininterrupta de palavras, fricciona-se sem descanso e um contra

mostravam a realidade de pobreza e violência das periferias, rompendo com o discurso de prosperidade propalado pelo neoliberalismo. 
os outros, língua, lábios e dentes. Projeta-se na performance vocal a violência gestual e das letras. Segundo Luiz Tatit, fundamentalmente em arrazoado exposto em seu livro O cancionista (1996), no Brasil, a canção nasceu como continuidade melodiosa da fala expressa no uso alongado de vogais, interagindo neste processo condições sociais que propiciaram a narrativa cantada da língua portuguesa. Baseado nesse argumento, pode-se afirmar que o canto do rap, calcado na diluição da melodia no meio das consoantes, é um produto genuíno da língua inglesa? Uma boa questão para ser analisada com mais rigor ${ }^{15}$. Especificamente no caso brasileiro, cabe destacar que Luiz Tatit (1996) formulou em seus estudos que sílabas cantadas sobre melodias que se alongam expressam melhor imagens passionais e subjetivas. Em contraposição, sílabas curtas e percussivas facilitariam o entendimento de imagens tangíveis. Pode-se extrair deste exemplo mais um casamento perfeito entre forma e conteúdo. O rap leva ao extremo a percussividade e diminui ao máximo a emissão melódica por entre as sílabas. Essa forma seria perfeita para as imagens tangíveis, narrações e descrições dos bairros pobres e da violência, tão recorrentes nesse gênero.

2) É império do ritmo contra a melodia. Não há passionalidade nem suavidade. A batida do ritmo bate na pele e incomoda, mexe, induz a ação, não deixa a escuta ser passiva. É música para o corpo que mexe, e para os ouvidos que assimilam a mensagem.

3) É tom menor e dissonância. Por vezes os instrumentos de acompanhamento produzem frases melódicas. Podem-se notar violões, teclados, pianos e instrumentos de sopro fazendo essa função. Na quase totalidade das vezes essas frases estão em escala menor. Produzem tensão, tristeza, raiva. Muitas vezes apela-se para a repetição das frases melódicas, induzindo cansaço, saturação. Algumas vezes produzem-se acordes com violão ou piano. Na maioria das vezes os acordes são menores

15 Cabe lembrar que muitos rockeiros brasileiros só cantam em inglês, afirmando que a língua portuguesa não possui a plasticidade necessária para a interpretação desse gênero musical. 
ou dissonantes. Provocam raiva, tristeza, incômodo. Reproduzidos à extenuação, induzem à sensação de tensão sem repouso.

4) A repetição da narrativa semi falada com a repetição da batida criam um transe por meio da monotonia. Assim como rituais religiosos, assim como a bateria de escola de samba. A narrativa torna-se monótona também. Não há indicação melódica de momentos mais ou menos importantes. Obriga a ter atenção à escuta ao mesmo tempo em que o corpo é induzido à ação. É pulso e letra.

5) Música sem refrão não canaliza tensões ${ }^{16}$. O refrão é o momento da canção onde as partes encontram o todo. Onde os indivíduos se fazem coletividade. É onde se forma o uno comunitário. É a condição e a prova do pertencimento. O refrão é textualmente, a síntese das particularidades expostas nas estrofes. Por isso mesmo o refrão é sempre onde entram as principais ideias da canção. O refrão anuncia o que as estrofes irão dirimir, investigar, exemplificar. O refrão é a síntese. Musicologicamente, o refrão é o alívio das tensões geradas pelas estrofes, no contínuo musicológico de tensão/distensão (WISNIK, 1989), assim como nossa respiração. Enfatizando: o rap, ao não ter refrão, é pura tensão. Tensão sem distensão. Tensão que não se resolve. Incômodo que não se acomoda. Escutar um rap é passar 10 minutos com a respiração suspensa. Não há refrão, não há repouso. Ao não resolver internamente suas tensões, o rap induz a buscar externamente à sua estrutura a possibilidade de resolução.

\section{Considerações Finais}

Não existe texto sem contexto, assim como não existe obra artística que não se relacione com o tempo histórico que é produzida. Desse modo, é fato que a potência e o sucesso dos Racionais MC's devem-se à capacidade que esse grupo teve de fazer

\footnotetext{
${ }_{16}$ Cabe lembrar que existem raps que possuem refrão. No entanto, é grande o número de exemplos nesse gênero musical que não possui refrão. Dada a essa amostra quantitativamente relevante, segue sendo pertinente realizar uma breve discussão sobre a ausência de refrão no rap.
} 
reverberar uma obra artística de qualidade, em conjunção com dinâmicas intrínsecas ao movimento hip-hop. No entanto, somadas a essas condições internas, havia um contexto que propiciou esse fenômeno. Esse foi o intuito deste artigo, demonstrar como condições históricas e artísticas se embasaram a visibilização que a obra do grupo obteve na passagem das décadas de 1980 a 1990.

De fato, o rap dos Racionais foi uma das experiências mais bem-sucedidas nas últimas décadas no que tange à busca pela recolocação do conflito na esfera pública. Essa tomada de posição ocorreu por meio de duas rupturas: uma musical e outra política, como já exposto no texto.

Por fim, cabe ressaltar o ineditismo e a potencialidade de formas musicais presentes no rap dos Racionais MC's que se coadunaram de maneira harmônica com o conteúdo proposto, contribuindo para o sucesso e a visibilização que a obra musical desse grupo obteve.

\section{Referências}

AB SÁBER, Tales. A Música do Tempo Infinito. Rio de Janeiro: Cosac Naify, 2012

ARANTES, Paulo. 1964: o ano que não terminou. In: TELES, Edson; SAFATLE, Vladimir (orgs.). O que resta da ditadura: a exceção brasileira. São Paulo: Boitempo, 2010.

CARRIL, Lourdes. Quilombo, Favela e Periferia. A Longa Busca da Cidadania. São Paulo: Annablume: Fapesp, 2006.

CUÍCA, Osvaldinho da; DOMINGUES, André. Batuqueiros da paulicéia. São Paulo: Barcarolla, 2009.

D'ANDREA, Tiaraju. A Formação dos Sujeitos Periféricos: Cultura e Política na Periferia de São Paulo. Tese de Doutorado. Departamento de Sociologia. FFLCH/USP, 2013.

Fim de Semana no Parque: vinte anos. Le Monde Diplomatique. Edição 76. Novembro, 2013.

DJ TR. Acorda Hip-Hop. Rio de Janeiro: Aeroplano, 2007.

GARCIA, Walter. Bim Bom. A Contradição Sem Conflitos de João Gilberto. São Paulo: Paz e Terra, 1999. 
Ouvindo Racionais MC's. In: Ensaios sobre Arte e Cultura na Formação. São Paulo: Anca/Coletivo Nacional de Cultura do MST, 2006.

HERSCHMANN, Micael. O Funk e o Hip-Hop invadem a cena. Rio de Janeiro, Editora UFRJ, 2005.

POCHMANN, Marcio. Nova Classe Média? O Trabalho na Base da Pirâmide Social Brasileira. São Paulo: Boitempo, 2012.

ROUGET, Gilbert. La Musique et la Transe. Paris: Éditions Gallimard, 1990.

SCHWARZ, Roberto. Cultura e Política: 1964-1969. In: . O Pai de Família e outros estudos. Rio de Janeiro: Paz e Terra, 1978.

SECCO, Lincoln. História do PT. Cotia: Ateliê Editorial, 2011.

SINGER, André. Os Sentidos do Lulismo. Reforma Gradual e Pacto Conservador. São Paulo: Companhia das Letras, 2012.

. Novas Expressões do Conservadorismo Brasileiro. Entrevista concedida a Luis Brasilino. Le Monde Diplomatique Brasil, Ano 6, n 63, outubro, 2012a, p. 20-21.

TATIT, Luis. Marchinha e Samba-Enredo. In: . Todos entoam. São Paulo: Publifolha, 2007. p. 200-202. . O Cancionista. São Paulo: Edusp, 1996.

TELLES, Vera da Silva. A cidade nas fronteiras do legal e ilegal. Belo Horizonte: Fino Traço Editora, 2012.

TROTTA, Felipe. O Samba e Suas Fronteiras. Rio de Janeiro: Editora UFRJ, 2011.

WISNIK, José Miguel. O Som e o Sentido. São Paulo: Companhia das Letras, 1989. 